\title{
KEBIJAKAN PEMACUAN SUMBERDAYA IKAN DI PERAIRAN UMUM DARATAN INDONESIA: TEKNOLOGI ALTERNATIF UNTUK MENINGKATKAN PRODUKSI IKAN DAN PENDAPATAN NELAYAN
}

\author{
Endi Setiadi Kartamihardja dan Chairulwan Umar \\ Peneliti pada Pusat Riset Perikanan Tangkap, Ancol-Jakarta \\ Teregistrasi I tanggal: 6 Pebruari 2007; Diterima setelah perbaikan tanggal: 26 Maret 2008; \\ Disetujui terbit tanggal: 25 April 2008
}

\begin{abstract}
ABSTRAK
Pemacuan sumberdaya ikan adalah suatu teknologi untuk meningkatkan hasil tangkapan ikan dan sekaligus pendapatan nelayan. Potensi produksi ikan perairan umum daratan Indonesia (luasnya 13,85 juta ha) ditaksir 3.034.934 ton/th, sedangkan produksi ikan yang telah dicapai 325.000 ton/th. Berdasarkan keberhasilan penerapan pemacuan sumber daya ikan di beberapa badan air, produksi ikan dapat ditingkatkan menjadi 1.452.947 ton/th. Ke depan, penerapan kebijakan pemacuan sumber daya ikan yang selama ini kurang didasarkan hasil kajian yang memadai perlu diperbaiki. Untuk setiap badan air perlu ditetapkan protokol pemacuan sumber daya ikan. Protokol tersebut meliputi identifikasi sumber daya perairan, menentukan tujuan penebaran, menentukan jenis, jumlah dan ukuran ikan, serta biaya yang diperlukan, mengembangkan strategi penebaran, monitoring dan evaluasi, serta pembentukan kelembagaan pengelolaan. Pedoman pemacuan sumber daya ikan di Indonesia perlu segera ditetapkan yang mengacu pada tata laksana perikanan yang bertanggungjawab.
\end{abstract}

KATA KUNCI: pemacuan sumber daya ikan, potensi produksi ikan, hasil tangkapan ikan, perairan umum daratan, Indonesia

ABSTRACT: Policy on fisheries enhancement in inland open waters of Indonesia: An option technology to increase fish production and fisher income. By: Endi Setiadi Kartamihardja and Chairulwan Umar

Fisheries enhancement is a technique to increase fish yield and fishers' income. Fish potential yield of inland open waters (13.85 million ha in area) was estimated at 3,034,934 ton/yr, while an average of the actual fish production was 325,000 ton/yr. Based on the success story of fisheries enhancement techniques applied in some water bodies, the fish yield total can be increased to be 1,452,947 ton/yr. In the future, application of policy on fisheries enhancement should be improved. Protocol on fisheries enhancement should be designed for every water body. The protocol should consit of identification of fisheries resources, establishment of the objective, determine a suitable fish species, optimum number and size of fish released, estimation of total cost, development of stocking strategy, monitoring and evaluation, and establishment of fisheries management unit. A guideline of fisheries enhancement in Indonesian inland open waters need to be constructed referring to code of conduct for responsible fisheries.

KEYWORDS: fisheries enhancement, fish potential yield, fish yield, inland open waters, Indonesia

Korespondensi Penulis:

Jl. Pasir Putih I, Ancol Timur-Jakarta 14430,E-mail: endi_prpt@indo.net.id 


\section{PENDAHULUAN}

Pemacuan stok ikan (fish stock enhancement) yang kemudian istilah berkembang lebih luas menjadi pemacuan sumber daya ikan (fisheries enhancement), didefinisikan sebagai aktivitas yang ditujukan untuk menambah atau melestarikan rekrutmen satu atau lebih organisme perairan dan meningkatkan total produksi atau unsur produksi yang dipilih dari suatu perikanan yang berada di bawah tingkat lestari dari proses alami (FAO, 1999). Dengan demikian, pemacuan stok ikan merupakan alat (tools) pengelolaan sumber daya ikan atau proses pengelolaan sumber daya dan sekarang merupakan upaya yang paling banyak dikerjakan orang. Pemacuan stok merupakan suatu teknik manipulasi stok untuk meningkatkan populasi ikan sehingga total hasil tangkapan atau hasil tangkapan jenis ikan tertentu meningkat (FAO, 1999; Welcomme \& Bartley, 1998), dan upaya ini dilakukan di perairan yang produktivitas alaminya tinggi, tetapi rekruitmen alaminya terbatas.

Dari definisi tersebut di atas tersirat bahwa pemacuan sumber daya ikan pada umumnya ditujukan untuk meningkatkan hasil tangkapan ikan atau memperbaiki populasi ikan karena populasi ikan di perairan tersebut menurun. Penurunan populasi ikan dapat diakibatkan oleh berbagai faktor, antara lain penangkapan yang intensif; perubahan habitat sehingga tidak sesuai dengan komunitas ikan asli, sumber daya pakan dan relung ekologis yang tidak dimanfaatkan secara optimal.

Pemacuan sumber daya ikan juga dimaksudkan untuk memperbaiki kuantitas dan kualitas stok ikan yang memijah sehingga memperbaiki potensi reproduksi alaminya. Dengan demikian, jika potensi reproduksi alami tersebut berhasil diperbaiki, maka dampak penebaran ikan terhadap pemacuan sumber daya ikan akan berlangsung lama sehingga tidak perlu dilakukan penebaran berulang-ulang.

\section{STATUS PEMACUAN SUMBER DAYA IKAN}

Praktek introduksi ikan telah dilakukan sejak penjajahan Belanda dan sampai saat ini tercatat tidak kurang dari 17 jenis ikan telah dimasukkan ke perairan umum daratan Indonesia (Sarnita, 1999). Ikan gabus (Channa striata) merupakan jenis ikan yang pertama kali dimasukkan ke Indonesia dari Cina bagian selatan dan kemudian pada tahun 1915, koan atau grass carp (Ctenopharyngodon idella), dan mud carp (Cirrhinus chinensis) dimasukkan dari Malaysia. Ikan mas (Cyprinus carpio) yang sekarang menjadi salah satu jenis ikan budidaya didatangkan dari Cina dan Jepang pada tahun 1920. Di antara jenis-jenis ikan introduksi tersebut, ikan gabus, mas, sepat siam (Trichogaster trichopterus), dan mujair (Oreochromis mossambicus) merupakan jenis yang dapat berkembang baik di beberapa perairan umum daratan Indonesia dan mendominasi hasil tangkapan nelayan.

Dari kegiatan pemacuan sumber daya ikan yang telah dilakukan tersebut, beberapa telah berhasil baik dalam meningkatkan hasil tangkapan, namun dalam jangka panjang keberhasilan praktek penebaran tersebut, dalam konteks keseimbangan lingkungan dan dukungan terhadap kehidupan masyarakat nelayan, banyak yang tidak berhasil. Introduksi ikan yang tidak didasarkan pada prinsip kehatihatian dan karakteristik limno biologi lingkungan perairan berdampak negatif terhadap penurunan keanekaragaman jenis ikan lokal. 
Pada hakekatnya, introduksi dan penebaran ikan yang disesuaikan dengan kondisi limno biologis perairan dan berorientasi menjaga keseimbangan ekologis telah terbukti meningkatkan produksi ikan perairan umum daratan dunia 20\% (FAO, 1999). Cina merupakan negara yang memperlihatkan peningkatan produksi ikan perairan umum tertinggi di dunia yang didongkrak dari kegiatan pemacuan stok ikan. Pemacuan stok ikan di danau telah meningkatkan rata-rata hasil tangkapan dari $710 \mathrm{~kg}$ per ha pada tahun 1995 menjadi $1.124 \mathrm{~kg}$ per ha tahun 2003 atau naik $58,3 \%$. Di perairan waduk, rata-rata hasil tangkapan ikan naik dari $538,1 \mathrm{~kg}$ per ha pada tahun 1995 menjadi $1.109 \mathrm{~kg}$ per ha pada tahun 2003 atau naik 106,1\% dan di perairan sungai, rata-rata hasil tangkapan ikan naik dari 1.336,9 kg per ha tahun 1995 menjadi $1.932 \mathrm{~kg}$ per ha pada tahun 2003 atau naik $44,5 \%$.

Meskipun aktivitas penebaran dan introduksi ikan sudah merupakan kegiatan rutin yang dilakukan di sebagian besar perairan umum daratan di Indonesia, namun berdasarkan data statistik perikanan terlihat bahwa produksi perikanan tangkap di perairan umum daratan tahun 2004 menunjukkan pencapaian yang stagnan, sekitar 300.000 ton per tahun. Nampak, kegiatan penebaran dan introduksi ikan tersebut diikuti dengan upaya rehabilitasi dan atau perbaikan habitat karena banyak perairan umum daratan yang mengalami degradasi lingkungan. Upaya penebaran dan introduksi ikan yang dilakukan juga pada umumnya belum didasarkan hasil kajian ilmiah yang memadai, hanya bersifat seremonial. Produksi ikan di suatu perairan dipengaruhi oleh berbagai faktor seperti komposisi komunitas ikan, produktivitas perairan, kualitas air yang masuk, bentuk alami dasar perairan, sistem penangkapan, dan pemasaran atau permintaan pasar (Kartamihardja et al., 1993; Sarnita, 1999).
Di Indonesia, beberapa contoh introduksi dan penebaran ikan yang berhasil adalah introduksi ikan mas ke Danau Tondano di Sulawesi Utara dalam periode tahun 19851991, yang mencapai $60 \%$ dari total produksi ikan $340 \mathrm{~kg}$ per ha (Sukadi \& Kartamihardja, 1995). Pada tahun 1937, ikan tawes (Barbodes gonionotus) diintroduksikan ke Danau Tempe di Sulawesi Selatan dan pada tahun 1940 dan 1948 telah menghasilkan produksi masingmasing 3.650 dan 25.000 ton. Total produksi ikan di danau ini terus meningkat dan dalam tahun 1963-1975, produksi ikan rata-rata mencapai $900 \mathrm{~kg}$ per ha per tahun (Sarnita, 1999), meskipun setelah itu produksi ikan terus menurun karena degradasi lingkungan.

Sejak tahun 2000, penelitian pemacuan sumber daya ikan mulai dilakukan dan diterapkan di beberapa perairan danau dan waduk. Kegiatan penelitian tersebut terus berlangsung dan semakin intensif setelah Departemen Kelautan dan Perikanan menetapkan Unit Pelaksana Teknis Riset Kelautan dan Perikanan, Pusat Riset Perikanan Tangkap, yaitu Loka Riset Pemacuan Stok Ikan yang berada di Jatiluhur untuk melaksanakan penelitian strategis di bidang pemacuan sumber daya ikan di perairan umum daratan dan laut. Beberapa hasil penelitian dan aplikasi yang berhasil baik di perairan umum daratan adalah introduksi ikan patin Siam (Pangasionodon hypopthalmus) di Waduk Wonogiri, Jawa Tengah pada tahun 2002. Setelah dua tahun penebaran yaitu tahun 2004 telah dapat meningkatkan hasil tangkapan ikan 112.215 $\mathrm{kg}$ dengan nilai Rp.785,5 juta serta menambah pendapatan nelayan Rp.1,2 juta per nelayan per tahun. Ikan patin yang ditebarkan juga dapat melakukan reproduksi secara alami sehingga untuk selanjutnya tidak perlu lagi dilakukan penebaran ulang. 
Contoh lainnya adalah introduksi udang galah di Waduk Darma, Jawa Barat yang menghasilkan produksi $337,65 \mathrm{~kg}$ atau senilai Rp.13,5 juta, walaupun udang galah yang ditebarkan hanya 26.500 ekor atau $26,5 \%$ dari jumlah optimum penebaran 100.000 ekor. Apabila penebaran udang galah dilakukan secara optimum, maka ditaksir akan dihasilkan produksi senilai Rp.70-140 juta per tahun yang merupakan pendapatan tambahan bagi 120 orang nelayan. Pada tahun 2003, introduksi ikan bilih (Mystacoleucus padangensis), satusatunya ikan endemik dari Danau Singkarak (Sumatera Barat) ke Danau Toba, Sumatera Utara dan pada tahun 2005 telah menghasilkan produksi 653,6 ton dengan nilai Rp.3,9 milyar.

Belajar dari berbagai contoh pemacuan sumber daya ikan yang berhasil dan yang gagal tersebut, upaya pemacuan sumber daya ikan perlu dievaluasi lebih lanjut. Paradigma lama tentang penebaran dan introduksi ikan yang selama ini dilakukan perlu diganti dengan paradigma baru sehingga upaya pemacuan sumber daya ikan dapat mencapai sasaran (Kotak 1). Dalam paradigma lama, penebaran dan introduksi ikan pada umumnya tidak pernah dievaluasi tingkat keberhasilan atau kegagalannya sehingga pelaksanaannya tanpa protokol yang jelas. Kegiatan penebaran ikan tersebut pada umumnya tidak didasarkan pada hasil kajian secara ilmiah, lebih bersifat coba-coba, seremonial dan mungkin politis, hanya sekedar seolaholah pemberian subsidi pada nelayan atau masyarakat setempat. Oleh karena itu, keberhasilan penebaran ikan di suatu perairan tidak pernah dapat menjawab pertanyaan kenapa penebaran tersebut berhasil dan begitu pula sebaliknya dengan kegagalan penebaran ikan.

Kotak 1. Paradigma pemacuan stok ikan

Box 1. Paradigma of fish stock enhancement

\begin{tabular}{|c|c|}
\hline Paradigma lama/OId paradigm & Paradigma baru/New paradigm \\
\hline $\begin{array}{l}\text { 1. Bersifat top-down atau instruktif dari pusat } \\
\text { atau pemerintah dan masyarakat kurang } \\
\text { dilibatkan/ } \\
\text { Charateristically top-down or instruction from } \\
\text { center or he government and sociciaty less } \\
\text { envoled }\end{array}$ & $\begin{array}{l}\text { 1. Melibatkan peran serta masyarakat dan } \\
\text { pemerintah bertindak sebagai mitra dan } \\
\text { fasilitator/ } \\
\text { Role of society envoled significantly and the } \\
\text { goverment plays as a partner and facilitator } \\
\text { as well }\end{array}$ \\
\hline $\begin{array}{l}\text { 2. Subsidi benih dari pemerintah terhadap } \\
\text { nelayan/ } \\
\text { Fish seed is subsidized by the government for } \\
\text { fishers }\end{array}$ & $\begin{array}{l}\text { 2. Benih ikan disediakan secara swadaya oleh } \\
\text { masyarakat nelayan/ } \\
\text { Fish seed is provided by fishers society them } \\
\text { self }\end{array}$ \\
\hline $\begin{array}{l}\text { 3. Tidak dilandasi pertimbangan data dan } \\
\text { informasi hasil kajian secara ilmiah dengan } \\
\text { protokol yang jelas/ } \\
\text { Does not use data and information from the } \\
\text { research results and clearl protocol }\end{array}$ & $\begin{array}{l}\text { 3. Dilandasi pertimbangan data dan informasi } \\
\text { hasil kajian secara ilmiah serta ada protokol } \\
\text { yang jelas/ } \\
\text { Using data and information from the research } \\
\text { results and clearl protocol }\end{array}$ \\
\hline $\begin{array}{l}\text { 4. Tidak ada monitoring dan evaluasi sehingga } \\
\text { tidak diketahui keberhasilan atau kegagalan } \\
\text { program/ } \\
\text { No monitoring and evaluation of the program, } \\
\text { so it could not measure wheather the program } \\
\text { is sucsessfull or fail }\end{array}$ & $\begin{array}{l}\text { 4. Dilakukan monitoring dan evaluasi yang } \\
\text { dilakukan oleh masyarakat bersama } \\
\text { pemerintah untuk mengetahui keberhasilan } \\
\text { atau kegagalan program/ } \\
\text { Monitoring and evaluation of the program is } \\
\text { done by society together by the government } \\
\text { to know wheather the program is sucsessfull } \\
\text { or fail }\end{array}$ \\
\hline
\end{tabular}




\section{PROTOKOL PEMACUAN SUMBER DAYA IKAN}

Metodologi atau cara pemacuan sumber daya ikan meliputi hal-hal sebagai berikut:

1. Penebaran untuk memacu atau mendukung kemampuan rekruitmen secara alami.

2. Rekayasa lingkungan atau modifikasi atau manipulasi habitat untuk memperbaiki laju rekruitmen dan atau pertumbuhan, jalur ruaya dan tempat perlindungan ikan, serta sumber daya pakan alami.

3. Eliminasi jenis-jenis ikan yang tidak dikehendaki.

4. Penyuburan perairan untuk meningkatkan produktivitas.

5. Introduksi jenis ikan baru dalam rangka optimalisasi pemanfaatan relung (niche) ekologi.

6. Penebaran ikan dalam rangka pengembangan perikanan berbasis budi daya (culture based fisheries).

Pada hakekatnya, agar program pemacuan sumber daya ikan berhasil, diperlukan protokol pemacuan stok ikan yang jelas, tahap demi tahap (Lampiran 1) dan secara garis besar meliputi identifikasi sumber daya perairan, menentukan tujuan penebaran, menentukan jenis, jumlah dan ukuran ikan serta biaya yang diperlukan, mengembangkan strategi penebaran, monitoring dan evaluasi serta pembentukan kelembagaan pengelolaan perikanan.

\section{Identifikasi Sumber Daya}

Identifikasi sumber daya perikanan dilakukan pada tahap awal untuk menentukan apakah stok ikan di perairan tersebut berada di bawah tingkat produksi optimum atau apakah kualitas stok ikan tersebut dapat ditingkatkan. Untuk itu, diperlukan pengkajian status stok ikan, penilaian kondisi perairan, dan faktor-faktor yang mungkin membatasi produksi. Hasil identifikasi sumber daya tersebut dituangkan dalam kerangka acuan logis (logical framework) sehingga secara tahap demi tahap akan memudahkan dalam menentukan tindakan yang diperlukan selanjutnya.

\section{Penentuan Tujuan Penebaran}

Jika dari hasil identifikasi sumber daya perikanan ternyata produksi ikan yang dicapai di bawah potensi, maka perlu diidentifikasi penyebabnya dan kemudian mencoba memecahkan penyebab tersebut sebelum penebaran ikan dilakukan. Penebaran ikan akan percuma dilakukan jika kegiatan tersebut tidak akan memberikan dampak peningkatan hasil tangkapan ikan dan menopang populasi ikan secara berkelanjutan. Pada perairan semacam ini mungkin sesuai jika dilakukan perbaikan habitat terlebih dahulu sebelum penebaran itu dilakukan sehingga ikan yang ditebarkan dapat melakukan reproduksi untuk kemudian meningkatkan stok ikan melalui rekruitment.

Mengetahui penyebab penurunan stok ikan di suatu perairan untuk kemudian dapat menanggulangi dan memecahkan masalahnya merupakan kegiatan yang dilakukan terlebih dahulu. Upaya perbaikan habitat yang ditujukan untuk meningkatkan rekruitmen jenis-jenis ikan asli merupakan alternatif terbaik dibandingkan dengan upaya penebaran atau introduksi ikan. Apalagi jika jenis ikan yang ditebarkan tersebut akan berdampak negatif terhadap populasi ikan asli. Oleh karena itu, keberhasilan perbaikan habitat merupakan perbaikan ekosistem secara berkelanjutan dengan dampak ekologis yang paling minimal. 


\section{Pengembangan Strategi Penebaran}

Jika keputusan untuk melakukan penebaran ikan telah ada, maka pelaksanaan rencana penebaran dilakukan secara hati-hati untuk meminimalkan risiko dan masalah potensial yang mungkin terjadi. Pelaksanaan penebaran perlu diformulasikan dengan baik melalui kajian sumber daya yang tersedia seperti ketersediaan benih, tenaga, transportasi, dan biaya. Di samping itu, perlu diidentifikasi kendala dan masalah yang mungkin akan menghambat keberhasilan penebaran. Protokol penebaran yang akan memberikan hasil semaksimal mungkin perlu ditetapkan, misalnya sumber benih, padat penebaran, ukuran dan umur ikan yang akan ditebar, waktu dan mekanisme penebaran. Pada Lampiran 2 diilustrasikan permasalahan sumber daya yang dipertimbangkan dalam rangka merencanakan penebaran ikan.

\section{Pengkajian Proposal Penebaran}

Faktor-faktor ekologis dan konsekuensi dari penebaran perlu dirumuskan secara jelas dan prediksi keuntungan dan kerugian diidentifikasi secara akurat. Proposal penebaran juga memuat kajian mengenai kemungkinan dampak terhadap potensi hasil tangkapan dan stabilitas stok ikan yang ditebarkan dan stok ikan asli. Resiko genetik dan perikanan serta pengaruh lingkungan yang berhubungan dengan aktivitas penebaran perlu didiskusikan secara rinci.

Perubahan yang berpengaruh terhadap sosial ekonomi perlu pula dievaluasi terutama yang berhubungan dengan biaya. Estimasi biaya meliputi pengeluaran dan hasil yang akan didapat dari adanya penebaran tersebut. Biaya penebaran tersebut perlu disosialisasikan kepada nelayan sehingga memungkinkan untuk dapat menyediakan biaya yang dibutuhkan.
Oleh karena itu, proposal penebaran tersebut perlu dibahas dengan mengikutsertakan sebanyak mungkin pelaku perikanan (stakeholders) di perairan tersebut. Dari hasil bahasan tersebut dapat ditarik kesimpulan apakah proposal penebaran tersebut dapat diterima atau ditolak.

\section{Monitoring dan Evaluasi}

Monitoring dan evaluasi merupakan kegiatan yang dilakukan setelah penebaran dilaksanakan. Kegiatan monitoring dan evaluasi dapat menghasilkan data dan informasi mengenai keberhasilan ataupun kegagalan penebaran. Oleh karena itu, penebaran tidak dilakukan jika setelah itu tidak akan ada kegiatan monitoring dan evaluasi. Pelaksanaan monitoring tersebut melibatkan masyarakat nelayan sehingga mengetahui secara pasti keberhasilan atau kegagalan penebaran tersebut. Evaluasi dilakukan untuk mengkaji efisiensi dan keuntungan jangka panjang serta mengidentifikasi faktor-faktor yang memberikan kontribusi terhadap keberhasilan atau kegagalan penebaran. Peningkatan hasil tangkapan sesaat belum tentu mengindikasikan keberhasilan penebaran karena ikan yang ditebarkan tidak dapat berkembangbiak sehingga tidak mendukung rekruitmen yang berkelanjutan.

\section{Pembentukan Pengelolaan Perikanan \\ Kelembagaan}

Tujuan pemerintah melakukan penebaran ikan adalah dalam rangka peningkatan produksi tangkapan ikan agar tingkat pendapatan atau kesejahteraan nelayan meningkat serta meningkatkan kebutuhan gizi masyarakat melalui penyediaan protein hewani dari ikan yang harganya terjangkau. Oleh karena itu, dana pemerintah terbatas tetapi sasarannya jelas yaitu nelayan, maka dalam upaya 
melestarikan sumber daya perikanan tersebut pemerintah (Pemerintah Daerah, Dinas Perikanan, otorita waduk atau danau, Balai Benih Ikan, lembaga penelitian) perlu bekerjasama dengan masyarakat nelayan maupun lembaga swadaya masyarakat sehingga terbentuk suatu kelembagaan perikanan yang akan mengelola perikanan secara terpadu, harmonis, dan lestari. Dalam pembentukan kelembagaan tersebut perlu ditetapkan secara jelas peran aktif dari masing-masing pelaku perikanan (stakeholders). Pembentukan kelembagaan perikanan ini akan semakin kompleks di perairan waduk dan danau yang bersifat multiguna, apalagi jika perikanan ditempatkan pada fungsi yang lebih rendah dari fungsi utama perairan tersebut. Peran kelembagaan perikanan tersebut secara ringkas ditunjukkan pada diagram alir (Lampiran 3).

Partisipasi aktif nelayan perlu ditumbuhkan sebagai bagian dari upaya mendidik nelayan agar timbul kesungguhan mereka dalam mentaati peraturan yang telah ditetapkan agar timbul rasa memiliki dan kesadaran mereka dalam memelihara kelestarian lingkungan dan sumber daya. Bentuk partisipasi nelayan yang perlu dibina dan langsung dapat dirasakan oleh nelayan misalnya dengan penggalangan dana pelestarian sumber daya ikan seperti yang sudah dilaksanakan di Waduk Wadaslintang (Wonosobo) dan Gajahmungkur (Wonogiri). Pemerintah, dalam hal ini Dinas Perikanan Kabupaten memiliki petugas perikanan yang tersebar di tingkat Kecamatan yang wilayahnya termasuk perairan waduk atau danau tersebut. Petugas perikanan Kecamatan tersebut bertugas membina beberapa kelompok nelayan desa (satu desa terdiri atas satu atau beberapa kelompok), diketuai oleh Ketua Kelompok dan beranggotakan para nelayan di desa tersebut (satu kelompok beranggota 20-30 orang). Secara berkala, Ketua Kelompok Nelayan mengadakan pertemuan di kecamatan atau mendapatkan pengarahan dari Dinas Perikanan Kabupaten tentang isu saat itu. Demikian pula, kegiatan kelompok secara berkala mengadakan semacam saresehan untuk membahas berbagai permasalahan yang dihadapi anggota dan juga menghimpun dana guna pembelian benih ikan untuk penebaran nanti. Pelaksanaan dengan bimbingan dan koordinasi dengan Dinas Perikanan setempat, baik mengenai jenis ikan, jumlah, lokasi, maupun waktu penebaran.

Pelaksanaan penebaran selanjutnya dilakukan oleh nelayan berdasarkan data dan informasi ilmiah hasil survei yang dilaksanakan oleh institusi atau lembaga penelitian yang terkait. Data dan informasi tersebut antara lain mengungkapkan hal-hal yang terkait dengan status produksi saat ini dan kondisi atau perkembangan populasi ikan serta dampak sosial ekonominya.

Lembaga penelitian dengan kelompok nelayan, Dinas Perikanan dan Otorita waduk merumuskan pola pengelolaan adaptif yang merupakan bagian yang tidak terpisahkan dari pengelolaan perairan secara terpadu dan harmonis dengan pemanfaat lainnya. Pola pengelolaan adaptif tersebut berubah secara dinamis disesuaikan dengan hasil monitoring dan evaluasi. Pengelolaan adaptif tersebut diarahkan pada terbentuknya pengelolaan perikanan secara bersama (fisheries co management).

\section{STRATEGI PEMACUAN SUMBER DAYA IKAN}

Strategi pemacuan sumber daya ikan secara sekilas telah dibahas pada sub bab pengembangan strategi penebaran. Berikut ini akan dibahas secara rinci dari berbagai hal yang dipertimbangkan dalam rangka penebaran ikan. 


\section{Sumber Benih}

Benih yang akan ditebarkan jelas sumbernya, apakah spesies tersebut berasal dari pembenihan atau penangkapan dari alam, apakah jumlahnya mencukupi dan mudah didapat. Asal benih juga ditujukan untuk meminimalkan resiko terhadap genetik dan lingkungan. Cowx (1994) mengajukan berbagai pilihan yang dipertimbangkan sebelum penebaran dilakukan, yaitu:

1. Jenis tebaran mempunyai karakteristik biologi yang sama dengan jenis yang ada di perairan yang akan ditebari.

2. Jenis yang berasal dari alam mempunyai karakteristik lingkungan yang hampir sama.

3. Benih yang berasal dari panti benih (hatchery), induknya cukup memadai sehingga menghindari variabilitas genetik.

4. Benih tebaran bebas penyakit dan parasit serta bersertifikat.

5. Jenis tebaran tidak menimbulkan masalah ekologis seperti penebaran dengan jenis ikan predator.

\section{Prakondisi dan Aklimatisasi}

Prakondisi dan aklimatisasi dimaksudkan agar jenis yang akan ditebarkan dapat menyesuaikan diri dengan lingkungan perairan baru sehingga tingkat kelangsungan hidupnya tinggi. Penyesuaian terhadap lingkungan ini berkaitan erat dengan suhu air. Sebelum spesies tersebut ditebarkan sebaiknya ditampung dulu di dalam wadah (jaring) yang ditempatkan di perairan yang akan ditebari. Penebaran baru dilakukan setelah spesies tersebut betul-betul sehat yang dapat dilihat dari gerakkannya yang lincah. Sebagai contoh, penebaran udang galah di Waduk Darma dan penebaran ikan patin siam di Waduk Wonogiri dilakukan setelah udang galah dan ikan tersebut dipelihara dalam kantong waring di waduk tersebut selama satu bulan.

\section{Penanganan dan Transportasi}

Penanganan dan transportasi yang kurang baik mengakibatkan ikan menjadi stres yang akhirnya dapat mematikan. Selama penanganan dan transportasi, ikan disimpan dalam wadah dengan kandungan oksigen normal terlarut yang tinggi, suhu air, dan kepadatan rendah. Cara-cara penanganan dan transportasi ikan yang baku perlu dilakukan. Sebelum ikan diangkut, ikan diberok dahulu, atau tidak diberi makan sekurang-kurangnya selama 24 jam. Pada pengangkutan yang lama, penggunaan obat bius dapat mengurangi stres karena mengurangi aktivitas fisik dan laju pernapasan ikan. Hal ini dilakukan terutama untuk pengangkutan ikan ukuran besar atau induk.

\section{Padat Penebaran}

Estimasi padat penebaran optimal perlu dilakukan agar penebaran tersebut berhasil sesuai dengan yang diharapkan. Namun demikian, analisis yang dilakukan terhadap data hasil penebaran ikan di beberapa negara dengan memasukkan dua variabel utama yang berperan, yakni luas lahan perairan yang ditebari dan padat penebaran, memberikan hasil yang kompleks (Welcome \& Bartley, 1998). Secara umum, data-data tersebut sulit untuk dianalisis dengan alasan sebagai berikut:

1. Hasil tangkapan berkorelasi dengan padat penebaran. Hubungan tersebut diasumsikan linier ataupun curvilinier, yaitu pada mulanya hasil tangkapan meningkat cepat dan akhirnya turun, karena faktor kepadatan (density dependent) mulai berpengaruh.

2. Hasil tangkapan per unit lahan berbanding terbalik dengan luas lahan. 
Penebaran terbukti berhasil baik di perairan yang relatif kecil dibandingkan dengan perairan yang luas. Hal ini antara lain disebabkan kemungkinan peluang terjadi kompetisi dan predasi lebih besar di badan air yang besar sehingga sintasan menurun.

3. Padat penebaran berbanding terbalik dengan luas danau. Praktek penebaran cenderung dilakukan dengan padat tebar yang rendah pada perairan yang relatif luas. Hal ini dilakukan dengan anggapan bahwa kompetisi dan predasi akan lebih besar di perairan yang luas sehingga sintasan akan berkurang, dan cara-cara peningkatan yang lainnya (penyuburan, pengendalian populasi ikan yang tidak diinginkan, atau konstruksi habitat buatan) lebih mudah dilakukan dan dikelola di perairan yang tidak luas. Pada kebanyakan kasus menunjukkan bahwa penebaran dengan kepadatan yang tinggi pada awalnya akan memberikan hasil yang besar, namun pada akhirnya akan menurun. Pada saat yang bersamaan karena padat penebaran meningkat, maka rata-rata bobot individu hasil tangkapan akan menurun terus sampai tidak dapat diterima oleh pasar. Jadi diperlukan upaya menjaga keseimbangan antara padat penebaran dan perkiraan ukuran ikan yang akan dihasilkan.

\section{Ukuran atau Umur Stok}

Ukuran atau umur ikan yang akan ditebarkan sangat berkaitan erat dengan faktor kelangsungan hidup dan biaya. Penebaran ikan dengan menggunakan ukuran kecil (misalnya fase larva) atau umur yang rendah akan menghasilkan kelangsungan hidup yang rendah pula. Ukuran ikan yang ditebar pula mempertimbangkan kemampuan adaptasi dan persaingan seperti predasi dan persaingan habitat. Sebagai contoh, udang galah yang ditebarkan di Waduk Darma pada ukuran 3-5 g per ekor dan ikan patin Siam yang ditebarkan di Waduk Wonogiri pada ukuran 10-20 g per ekor menunjukkan kelangsungan hidup yang baik.

\section{Waktu dan Mekanisme Penebaran}

Waktu penebaran yang paling baik adalah pada saat kualitas perairan baik. Seperti diketahui bahwa di perairan waduk atau danau yang mempunyai fluktuasi permukaan air tinggi, pada umumnya kualitas air akan menurun pada waktu permukaan air rendah sampai saat permukaan air mulai meningkat. Oleh karena itu, penebaran sebaiknya dilakukan pada waktu permukaan air tinggi. Pada waktu tersebut kelimpahan sumber daya pakan juga meningkat sebagai hasil dari perendaman kembali lahan daratan yang semula kekeringan.

Cowx (1994) mengatakan tiga mekanisme penebaran sebagai berikut:

1. Penebaran di satu titik (spot planting), penebaran seluruh ikan dilakukan pada satu daerah tertentu.

2. Penebaran secara menyebar (scatter planting), penebaran ikan dilakukan pada beberapa lokasi dalam satu wilayah.

3. Penebaran secara bertahap (trickle planting): penebaran dilakukan dalam 1 wilayah selama periode waktu tertentu.

Dalam pelaksanaan penebaran atau introduksi ikan tersebut, pertimbanganpertimbangan resiko potensial yang akan timbul baik resiko genetis, ekologis dan lingkungan, serta sosial ekonomis perlu diantisipasi terlebih dahulu. Dengan demikian, pelaksanaan penebaran mengacu pada tata laksana perikanan yang bertanggungjawab (code of conduct for responsible fisheries). 


\section{REKOMENDASI KEBIJAKAN}

1. Pemacuan sumber daya ikan termasuk di dalamnya pemacuan stok adalah kegiatan yang sudah waktunya diterapkan oleh Departemen Kelautan dan Perikanan di perairan umum daratan Indonesia untuk meningkatkan hasil tangkapan dan sekaligus meningkatkan pendapatan nelayan. Dengan penerapan pemacuan sumber daya ikan, produksi ikan di perairan umum daratan dapat ditingkatkan sampai mencapai 1.452.947 ton per tahun atau sekitar $149 \%$ dari produksi ikan yang telah dicapai saat ini.

2. Pemacuan sumber daya ikan yang selama ini kurang didasarkan pada hasil kajian ilmiah yang memadai perlu dievaluasi dan untuk setiap badan air perlu ditetapkan protokol pemacuan sumber daya ikan oleh Departemen Kelautan dan Perikanan. Protokol pemacuan sumber daya ikan meliputi identifikasi sumber daya perairan, menentukan tujuan penebaran, menentukan jenis, jumlah dan ukuran ikan, serta biaya yang diperlukan, mengembangkan strategi penebaran, monitoring dan evaluasi serta pembentukan kelembagaan.

3. Pedoman pemacuan sumber daya ikan untuk perairan Indonesia perlu segera ditetapkan Departemen Kelautan dan Perikanan dengan mengacu pada tata laksana perikanan yang bertanggungjawab (code of conduct for responsible fisheries).

\section{DAFTAR PUSTAKA}

FAO. 1999. Review of the state of world fishery resources: inland fisheries. FAO Fisheries Circular. No.942. Rome. 53 pp.
Sarnita, A. S. 1999. Introduction and stocking of freshwater fishes into inland waters of Indonesia. In W. L. T. van Densen \& M. J. Morris (Eds). Fish and Fisheries of Lakes and Reservoirs in Southeast Asia and Africa. Westbury Academic and Scientific Publishing. Otley. West Yorkshire. U. K. 143-150.

Kartamihardja, E. S., Krismono, \& K. Purnomo. 1993. Kondisi ekologis dan potensi sumber daya perikanan perairan umum danau dan waduk. Prosiding Temu Karya IImiah Perikanan Perairan Umum. Pengkajian Potensi dan Prospek Pengembangan Perikanan Perairan Umum Sumatera Bagian Selatan. Palembang 12-13 Pebruari 1992. Pusat Penelitian dan Pengembangan Perikanan. Jakarta. p.37-45.

Sukadi, M. F. \& Kartamihardja, E. S. 1995. The status of inland fisheries in Indonesia. Country Report Presented at the IPFC Working Party of Experts on Inland Fisheries. Bangkok. Thailand 17-21 October 1994. FAO. UN.

Cowx, L. G. 1994. Stocking strategy. Fisheries Management and Ecology. (1): 15-30.

Welcomme, R. L. \& D. M. Bartley. 1998. An evaluation of present techniques for the enhancement of fisheries. p. 1-36. In T. Petr (ed). Inland fishery enhancements. FAO Fish. Tech. Pap. No.374. Rome. 
Lampiran 1. Diagram alir protokol dan strategi pemacuan stok

Sumber: Cowx (1994)

Appendix 1. Flow diagram of protocol and strategy of fish stock enhancement Sources: Cowx (1994)

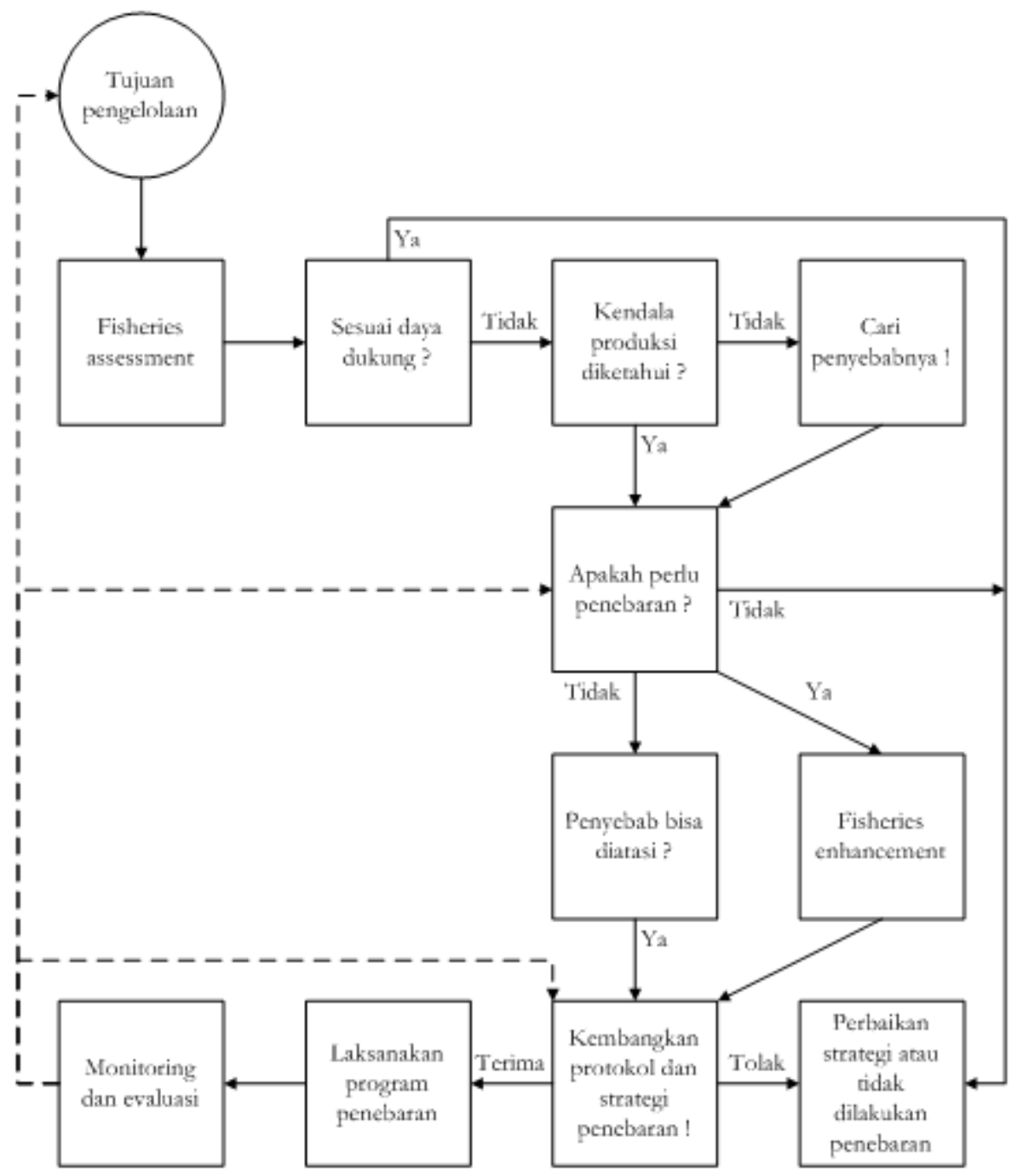


Lampiran 2. Diagram alir permasalahan sumber daya perikanan yang dipertimbangkan dalam perencanaan penebaran

Sumber: Cowx (1994)

Appendix 2. Flow diagram of fisheries resource problems should be considered in fish stocking plan

Sources: Cowx (1994)

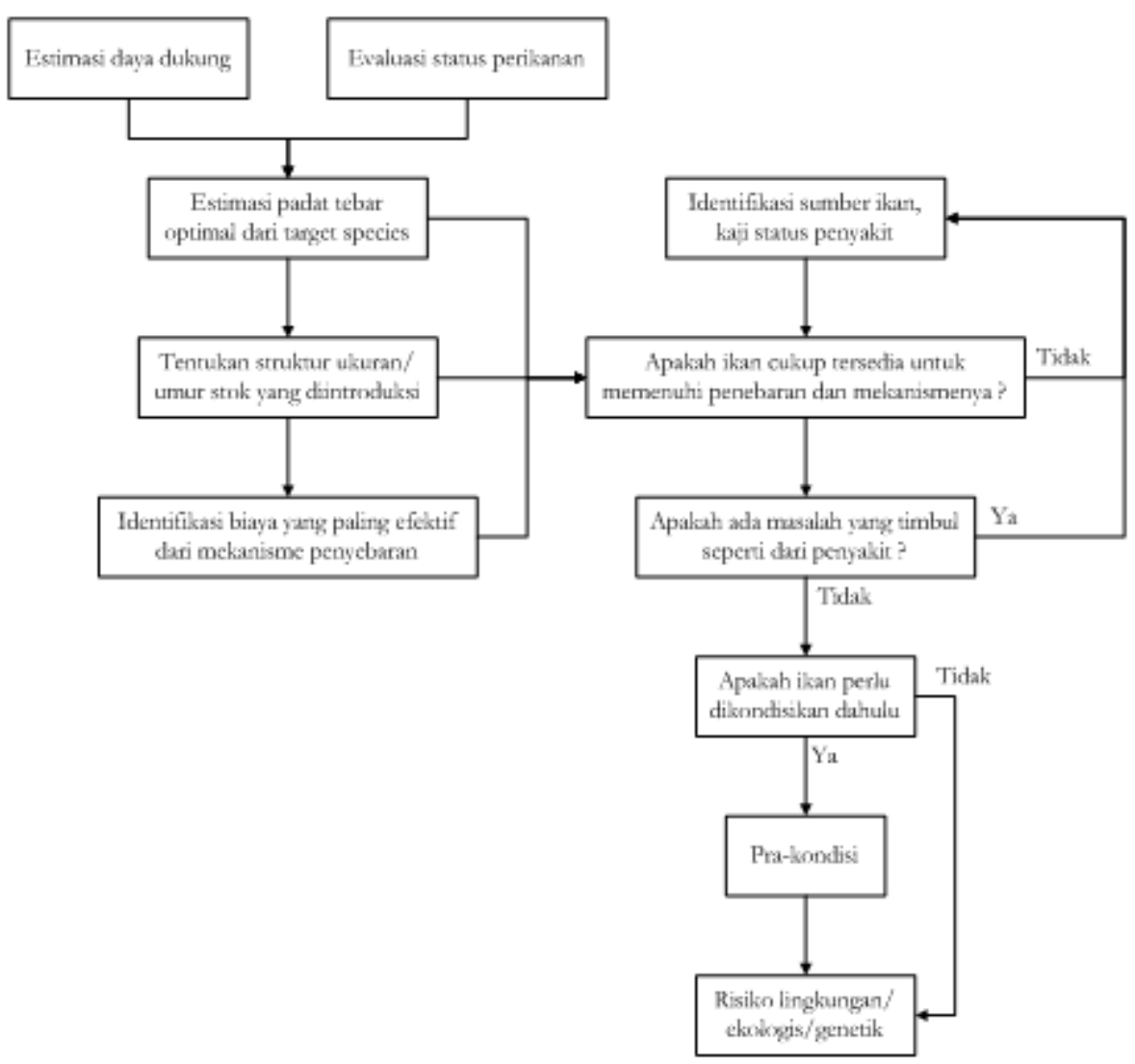


Lampiran 3. Diagram alir peran kelembagaan utama dalam pengelolaan perikanan di perairan waduk dan danau

Appendix 3. Flow diagram of the role of main institution in fiheries management in manmade lake and lake

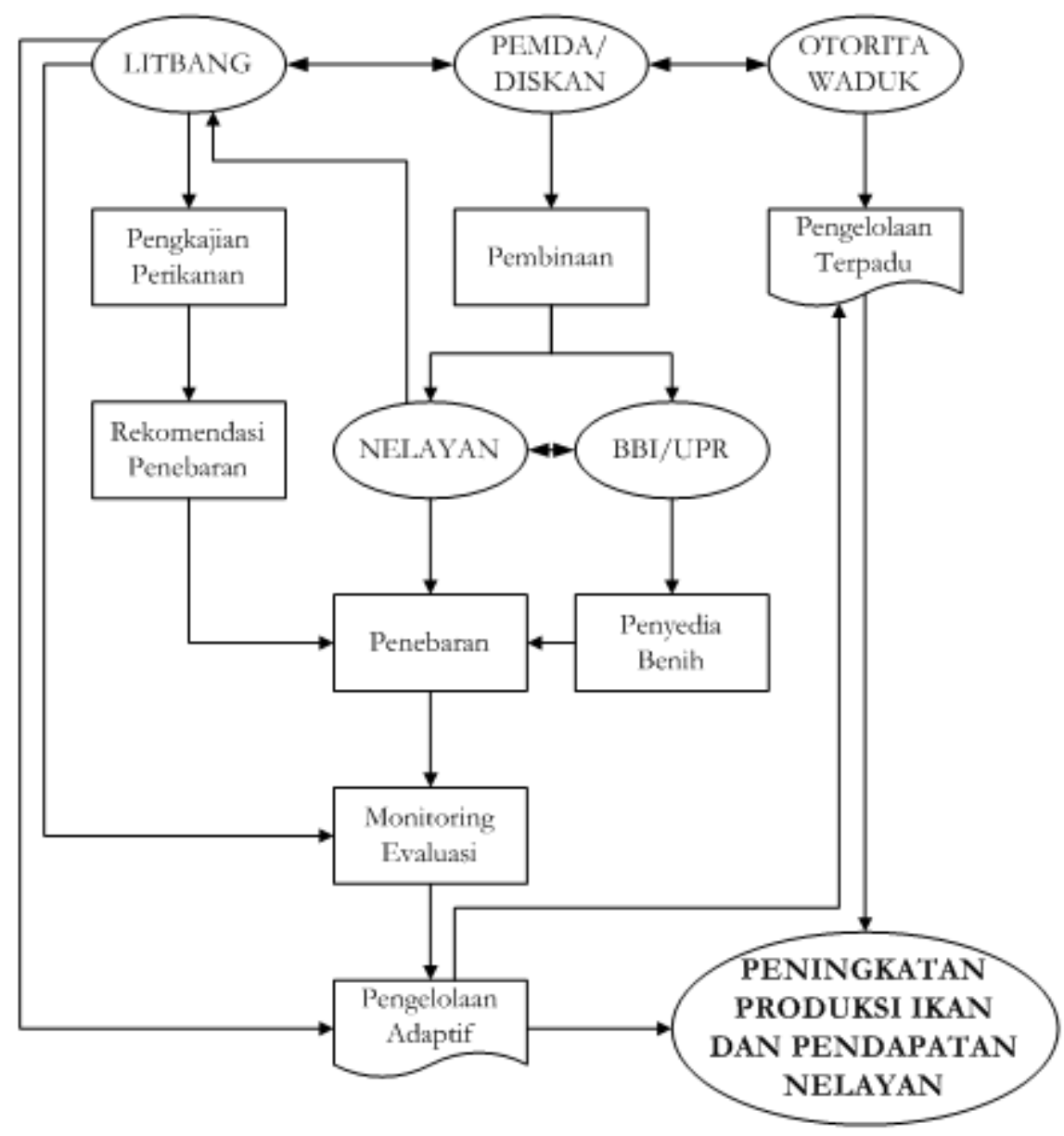

Keterangan/Remarks: LITBANG: Lembaga Penelitian dan Pengembangan/Institution of Reserach and Development; PEMDA: Pemerintan Daerah/District Government; DISKAN: Dinas Perikanan/Fisheries Extension Services; BBI: Balai Benih Ikan/Goverment Hatcheries; UPR: Unit Pembenihan Rakyat/ Farmers' Hatcheries Unit 